\title{
Frost flower surface area and chemistry as a function of salinity and temperature
}

\author{
Rachel W. Obbard, ${ }^{1}$ Howard K. Roscoe, ${ }^{1}$ Eric W. Wolff, ${ }^{1}$ and Helen M. Atkinson ${ }^{1}$ \\ Received 13 May 2009; revised 21 July 2009; accepted 29 July 2009; published 24 October 2009.
}

[1] Frost flowers play a role in air-ice exchange in polar regions, contribute to tropospheric halogen chemistry, and affect ice core interpretation. Frost flowers were observed and collected on the Hudson Bay in March 2008. Their specific surface area (SSA) was measured using $\mathrm{CH}_{4}$ adsorption at $77 \mathrm{~K}$. The Brunauer-Emmett-Teller analysis produced SSA values between 63 and $299 \mathrm{~cm}^{2} \mathrm{~g}^{-1}$ (mean $162 \mathrm{~cm}^{2} \mathrm{~g}^{-1}$, accuracy and reproducibility $5 \%$ ). This range is very similar to that of Dominé et al. (2005) but our correlation of results with growth time and chemistry reveals the factors responsible for the wide range of SSA values. Longer growth time leads to higher SSA at low temperatures, so frost flowers are more likely to affect total surface area during colder periods. Chemical analysis was performed on frost flower melt and on local seawater and brine. We examined salinity and sulfate and bromide enrichment. The relationship between growth time and salinity varied spatially because of a freshwater plume from a nearby river and of tidal effects at the coast. Enrichment of certain ions in frost flowers, which affects their contribution to atmospheric chemistry, depends heavily on location, growth time, and temperature. No significant enrichment or depletion of bromide was detected. The low surface area index of frost flowers plus their lack of destruction in wind suggest their direct effect on sea salt mobilization and halogen chemistry may be less than previously thought, but their ability to salinate wind-blown snow may increase their indirect importance.

Citation: Obbard, R. W., H. K. Roscoe, E. W. Wolff, and H. M. Atkinson (2009), Frost flower surface area and chemistry as a function of salinity and temperature, J. Geophys. Res., 114, D20305, doi:10.1029/2009JD012481.

\section{Introduction}

[2] This study of Arctic frost flowers (FF) was part of an International Polar Year project focused on the impact of combined iodine and bromine release on the Arctic atmosphere (COBRA). In both Arctic and Antarctic coastal regions, polar sunrise brings episodes of tropospheric ozone depletion which are associated with the exchange of bromine species between the ice and the lower troposphere [Bottenheim et al., 1986, 2002; Roscoe et al., 2001; Spicer et al., 2002]. Bromine compounds destroy ozone, and sea salt is their source in the polar troposphere. Details of their mobilization have been the subject of much recent research, and it is hypothesized that the brine and frost flowers found on the surface of new sea ice are responsible [e.g., Kaleschke et al., 2004].

[3] Enhanced tropospheric $\mathrm{BrO}$ and marked ozone depletion events (ODEs) have been observed at the Hudson Bay [Carpenter et al., 2005], where the present study was conducted. The University of Laval field station (Centre d'Étude Nordique de l'Université Laval) in Kuujjuarapik, Quebec, provided a long-term record of atmospheric and

\footnotetext{
${ }^{1}$ British Antarctic Survey, Cambridge, UK.
}

Copyright 2009 by the American Geophysical Union. 0148-0227/09/2009JD012481 meteorological measurements, a base from which to conduct field experiments, and a location in which to run a Brunauer-Emmett-Teller (BET) surface area measurement apparatus.

[4] ODEs are observed in air masses that have passed over new sea ice [Hopper et al., 1998; Richter et al., 1998; Wagner et al., 2001], consistent with the idea that bromine compounds released from frost flowers are responsible. Through autocatalytic reactions, bromide ions in sea salt become bromine gas $\left(\mathrm{Br}_{2}\right)$, which is photodissociated to $\mathrm{Br}$ atoms that then destroy ozone in the process [Barrie et al., 1988; McConnell et al., 1992; Fan and Jacob, 1992; Foster et al., 2001].

[5] Frost flowers, which first became of interest as a source of variations in the albedo and remote sensing signature of sea ice [Makshtas, 1991], grow from the vapor and are found on the surface of newly formed ice [Perovich and Richter-Menge, 1994]. A thin liquid layer on the surface of sea ice may be a source of salty liquid to salinate frost flowers. Brine expelled from brine channels during further freezing leads to frost flowers' high bulk salinity, at least until they collect blowing snow and additional hoarfrost [Perovich and Richter-Menge, 1994; Drinkwater and Crocker, 1988; Crocker and Lewis, 1985].

[6] Frost flowers are also of interest because their aerosol may provide an indicator of sea ice extent in ice cores in the interior of Greenland and Antarctica [Wolff et al., 2003]. An 
important proxy for climate change is the non-sea-salt sulfate found in ice cores. Sulfate depletion in ice cores from inland locations has been attributed to the formation of new sea ice in the area from which the wind is coming [Rankin et al., 2000, 2002].

[7] In addition to providing a concentrated source of sea salt, frost flowers were thought to provide a large surface area for chemical reactions [Rankin et al., 2002]. This surface area is usually quantified as specific surface area (SSA), the surface area available to gases per unit mass.

[8] In this paper, we compare chemical and physical variations between frost flowers from different locations to provide further insights to their growth and to illustrate factors that could be treated explicitly in global atmospheric models.

\subsection{Frost Flower Formation, Morphology, and Growth}

[9] Frost flowers are found often, but not exclusively, on the new sea ice that forms on open water leads [Perovich and Richter-Menge, 1994]. Leads open in sea ice due to the influence of winds, tides, and currents. When they do, water near to $0^{\circ} \mathrm{C}$ is exposed to colder air, resulting in the rapid growth of ice and the simultaneous expulsion of salts both to the water below (gravity drainage) and outward to form brine channels to the surface. As a result, a highly saline surface skim, typically $5-10^{\circ} \mathrm{C}$ warmer than the air temperature, forms on the new sea ice [Perovich and RichterMenge, 1994]. As time passes and the sea ice becomes thicker, it provides a greater thermally insulating barrier between the warmer sea and colder air above, allowing the uppermost part of the sea ice to cool [Perovich and RichterMenge, 1994]. This causes further ice formation and narrowing of the brine channels. Where brine channels become pinched off, further expansion of the freezing ice causes brine to be forced out to the surface.

[10] The surface skim serves as a source of excess water vapor, resulting in supersaturation near the surface; small crystals nucleate on imperfections on the surface of the sea ice and grow by vapor deposition; they spread, eventually forming a dense blanket of frost flowers [Perovich and Richter-Menge, 1994]. Frost flowers standing on a brinewetted surface will wick up brine, through the effects of surface tension and concentration gradients, and increase in bulk salinity [Perovich and Richter-Menge, 1994; Rankin et al., 2000; Alvarez-Aviles et al., 2008].

[11] In their study, Alvarez-Aviles et al. [2008] found bulk salinities of frost flowers growing on the open ocean near Barrow, Alaska, ranging from 16 to $105 \%$, with an average of $62 \%$. The tips of mature frost flowers are less saline, attributed to vapor deposition as a greater source of material there than wicking [Alvarez-Aviles et al., 2008]. Bulk salinity decreases at night as temperatures drop and additional hoarfrost accumulates, and frost flowers are extremely effective collectors of snow. These two effects reduce their bulk salinity over time [Perovich and Richter-Menge, 1994].

[12] Frost flowers increase the surface area available for chemical reactions. How much they do so is a function of morphology, areal coverage, and height. Much has been published on the growth of snow from water vapor in clouds, the consensus being that morphology and habit depend on air temperature and supersaturation relative to ice [Mason, 1992]. Between 0 and $-5^{\circ} \mathrm{C}$, the predominant crystal type is a thin hexagonal plate. Between -3 and $-8^{\circ} \mathrm{C}$, needles and hollow hexagonal columns form. Hexagonal plates, sector plates, and dendrites form between -8 and $-25^{\circ} \mathrm{C}$, and below $-25^{\circ} \mathrm{C}$, prismatic columns or rods and clusters of hollow columns are found [Mason, 1992; Martin et al., 1996]. When the local air temperature or degree of supersaturation changes during growth, the shape of crystal tips changes as well [Mason, 1992; Martin et al., 1996; Nelson, 2001]. At high supersaturation, the tip shape of primary branches will be round, leading to a stellar crystal without side branches. At lower supersaturation, the tip will be faceted, and side branches will form to create a dendritic crystal [Gonda and Nakahara, 1997]. These dependencies on temperature and supersaturation appear to hold true for frost flowers as well [Martin et al., 1996; Dominé et al., 2005; Alvarez-Aviles et al., 2008].

[13] The relevant temperature for frost flower morphology is the temperature at the ice surface in the immediate vicinity of the frost flowers. This is a function not only of air and water temperatures but of ice thickness and porosity, snow cover, and even the frost flower blanket itself [Martin et al., 1996]. Seawater cannot cool below -1.9 to $2.0^{\circ} \mathrm{C}$, depending on salinity. Sea ice on its surface acts as an insulator between the warmer water below and colder air above, permitting colder surface temperatures as it thickens. The thermal conductivity of sea ice depends on its porosity but is on the order of $2 \mathrm{~W} \mathrm{~m}^{-1} \mathrm{~K}^{-1}$, whereas that of snow is 0.14-0.33 $\mathrm{W} \mathrm{m}^{-1} \mathrm{~K}^{-1}$ [Thomas and Dieckmann, 2003]. Hence, even a few centimeters of snow on sea ice $50 \mathrm{~cm}$ thick can double its insulation. Also, the scale of lateral heat transport in sea ice is on the order of $10 \mathrm{~m}$, so the temperature at the surface of a narrow section of new, uncovered sea ice is significantly affected by snow covering the surrounding ice [Sturm et al., 2002]. Finally, the frost flowers themselves have been demonstrated to be $4-6^{\circ} \mathrm{C}$ warmer than the surrounding air and to have an insulating effect, causing the ice substrate where they grow to be $1-$ $2{ }^{\circ} \mathrm{C}$ warmer than the surrounding bare ice [Martin et al., 1996].

[14] Part of the interest surrounding frost flowers has been their potential to increase the available surface area at the sea ice surface. The amount of this increase has been a matter of some conjecture. Frost flowers on sea ice were initially estimated to yield total surface areas somewhere between 50 and $1000 \mathrm{~m}^{2} \mathrm{~m}^{-2}$, based on previously measured SSA of snow, which ranged from 0.2 to $2.25 \mathrm{~m}^{2} \mathrm{~g}^{-1}$ [Hoff et al., 1998; Hanot and Dominé, 1999], and the estimated mass per unit area of frost flowers of $0.025-$ $0.050 \mathrm{~g} \mathrm{~cm}^{-2}$ [Perovich and Richter-Menge, 1994; Rankin et al., 2002]. More recently, the SSA of frost flowers was measured directly, through methane adsorption at $77 \mathrm{~K}$, with results of $185(+80-50) \mathrm{cm}^{2} \mathrm{~g}^{-1}$, suggesting a total surface area increase for dry frost flowers of only $1.4 \mathrm{~m}^{2} \mathrm{~m}^{-2}$ [Dominé et al., 2005].

\subsection{Frost Flower Chemistry}

[15] The microstructural chemistry of frost flowers is complex, relying as it does on the conditions when they form, air and substrate temperature, chemical concentrations in the water and surface skim, and relative humidity, and on 


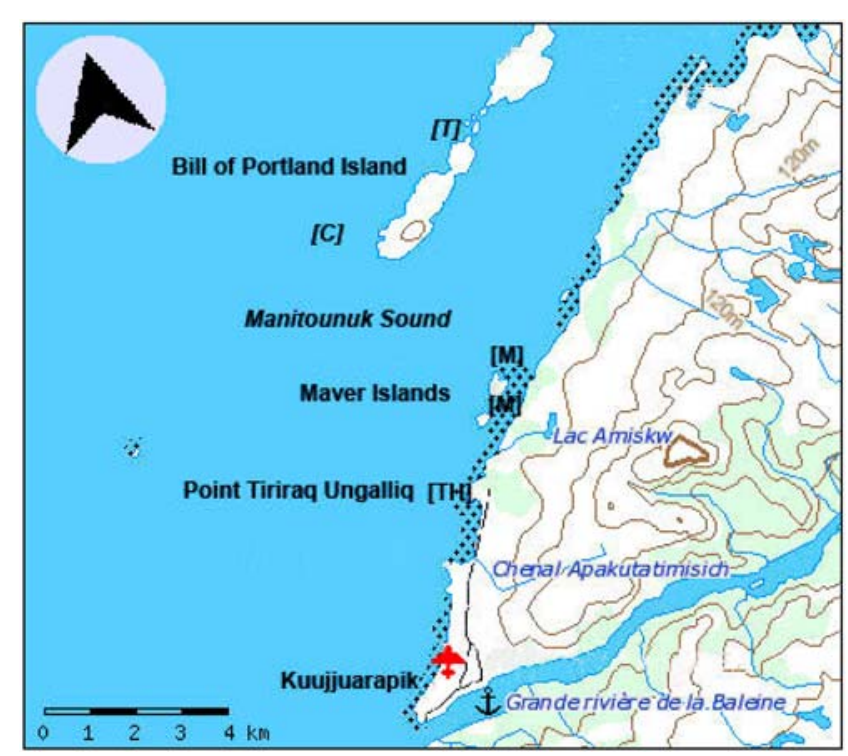

Figure 1. Topographical map of Kuujjuarapik area. Shaded areas are shallow water. Locations of frost flower collection are shown: Crack (C), $55^{\circ} 21^{\prime} 33^{\prime \prime} \mathrm{N}, 77^{\circ} 44^{\prime} 49^{\prime \prime} \mathrm{W}$; Tidal pool off northwest tip of Bill of Portland Island (T), $55^{\circ} 22^{\prime} 31^{\prime \prime} \mathrm{N}, 77^{\circ} 41^{\prime} 47^{\prime \prime} \mathrm{W}$; tidal pools at Maver Islands (M), $55^{\circ} 19^{\prime} 39^{\prime \prime} \mathrm{N}, 77^{\circ} 43^{\prime} 40^{\prime \prime} \mathrm{W}$; and test hole $(\mathrm{TH}), 55^{\circ} 18^{\prime} 89^{\prime \prime} \mathrm{N}$, $77^{\circ} 44^{\prime} 20^{\prime \prime} \mathrm{W}$.

changes in all of these conditions plus the availability of additional precipitation as they grow.

[16] An important aspect is the fractionation of sodium and sulfate relative to chloride as a result of the precipitation of their salts [Alvarez-Aviles et al., 2008]. As the temperature drops, the brine rejected from the brine channels becomes progressively more concentrated. This is especially pronounced at the surface, where the air above the ice is much colder and where the diluting effect of the larger body of water is not felt. At colder temperatures, salts begin to precipitate, e.g., mirabilite $\left(\mathrm{Na}_{2} \mathrm{SO}_{4} \cdot 10 \mathrm{H}_{2} \mathrm{O}\right)$ at $-8^{\circ} \mathrm{C}$, hydrohalite $\left(\mathrm{NaCl} \cdot 2 \mathrm{H}_{2} \mathrm{O}\right)$ at $-22^{\circ} \mathrm{C}$, and potassium and magnesium salts at $-34^{\circ} \mathrm{C}$. The precipitation of these salts changes the relative ion concentrations in the liquid and in the frost flowers [Rankin et al., 2000, 2002]. Below $-8^{\circ} \mathrm{C}$, loss of sodium and sulfate increases with decreasing temperature, and aerosol from frost flowers formed at these temperatures would be depleted in sodium and sulfate relative to other ions [Rankin et al., 2000, 2002]. Further, mirabilite precipitation will remove a greater proportion of the sulfate than of the sodium and the resulting frost flower aerosol will have a higher sodium to sulfate ratio than aerosol generated from seawater [Rankin et al., 2000, 2002]. Below $-22^{\circ} \mathrm{C}$, precipitation of hydrohalite $(\mathrm{NaCl}$. $2 \mathrm{H}_{2} \mathrm{O}$ ) will affect the fractionation of other ions with respect to chloride, in particular increasing the ratio of bromide to chloride.

[17] Alvarez-Aviles et al. [2008] calculated the enrichment factors $\left(E_{f}\right)$ of sulfate and bromide in frost flowers near Barrow, Alaska (air temperature $-22^{\circ} \mathrm{C}$ ), with respect to chloride to compare their ion concentration ratios to those of standard seawater. $E_{f}\left(\mathrm{SO}_{4}^{2-}\right)$ showed enrichment at low frost flower salinity but approached unity as salinity increased toward bulk ocean values [Alvarez-Aviles et al., 2008]. They found no significant enrichment or depletion of $\mathrm{Br}^{-}$, but this does not address the question of whether enough bromide had been earlier released to take part in ODEs. A decrease of only $0.5 \%$ in bromide in frost flowers is needed to release enough bromine to the atmosphere to create an ODE [Alvarez-Aviles et al., 2008], and such a small change would probably be undetectable. Simpson et al. [2005] found approximately $10 \%$ bromide enrichment, relative to sodium, in frost flowers collected from the same area near Barrow, Alaska, the previous year March-May 2004 (air temperature $\sim-25^{\circ} \mathrm{C}$ ). It is possible that hydrohalite precipitation led to a lower than expected $\mathrm{Na}$ ion concentration in the frost flowers, which contributed to this finding.

\section{Methods}

\subsection{Location and Sampling}

[18] River discharge affects upper ocean salinity, thermohaline circulation, and sea ice formation on both regional and global scales, as rivers produce a shallow buoyant plume in adjacent coastal waters [Déry et al., 2005; Ingram and Larouche, 1987]. Background surface salinity in the Hudson Bay is typically 29 practical salinity units (psu) in February, when most of the bay is covered by seasonal sea ice, but shoreline surface salinity is greatly affected by the 42 major rivers that drain into the bay [Ingram and Larouche, 1987]. In the southeastern part of the bay, the Great Whale River, or Grande Rivière de la Baleine, produces a mean annual discharge of $19.77 \mathrm{~km}^{3} \mathrm{yr}^{-1}$ at Kuujjuarapik, Quebec [Déry et al., 2005; Ingram and Larouche, 1987; Li and Ingram, 2007]. While the flow varies interannually and seasonally, the velocity of the freshwater discharge at the river's mouth compared to the tidal current results in a freshwater plume even under midwinter ice [Ingram, 1981; Ingram and Larouche, 1987; Li and Ingram, 2007].

[19] Great Whale River plume dynamics vary with river discharge, tidal amplitude, sea ice cover and age, wind, water column stability, and coastal water circulation. Plume areal coverage, as seen in isohalines, can extend alongshore or radially from the mouth of the river [Ingram and Larouche, 1987]. Published surface isohalines for February and March in previous years show the area between the mainland and the Bill of Portland Island within the $5 \mathrm{psu}$ isohaline, while the area immediately west of the Bill of Portland Island ranges in salinity from 5 to 25 psu [Ingram and Larouche, 1987].

[20] The experimental site was located $8 \mathrm{~km}$ north of the mouth of the river, where the sea ice was $60-130 \mathrm{~cm}$ thick (Figure 1). An open water lead formed $6 \mathrm{~km}$ west of Point Tiriraq Ungalliq early in our campaign but then refroze, and there were no open leads in the area during the study period. Hence, frost flowers were collected from test holes $1 \mathrm{~m}$ square and cut in the ice $50 \mathrm{~m}$ from shore, from a large crack (15 cm deep and 20 to $30 \mathrm{~cm}$ wide) that formed west of Bill of Portland Island and from tidal pools on the northernmost tips of the Bill of Portland and Maver Islands. Water depth is less than $10 \mathrm{~m}$ under the test holes and in the Manitounuk Sound around the Maver Islands, and then increases rapidly to $50 \mathrm{~m}$ west of Bill of Portland Island [Ingram, 1981; Ingram and Larouche, 1987]. The $1 \mathrm{~m}^{2}$ test hole was made by removing $1.3 \mathrm{~m}$ thick ice with a saw at 
Temperatures $\left({ }^{\circ} \mathrm{C}\right) \quad$ Air $\mathrm{T}=-23.0^{\circ} \mathrm{C}$

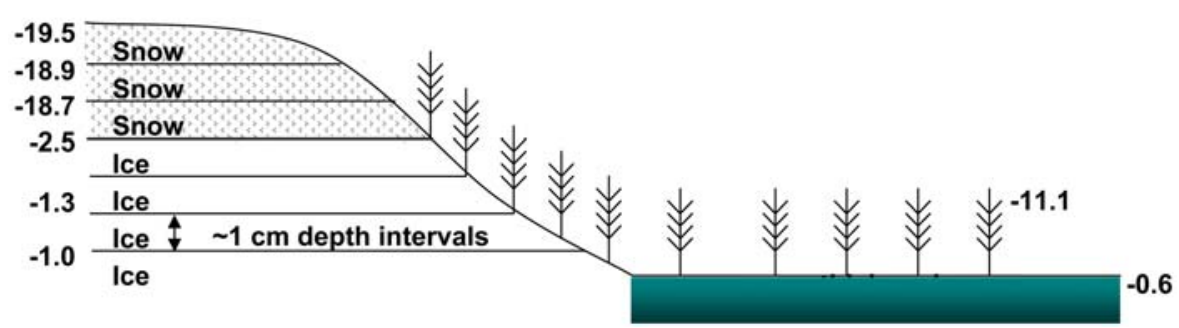

Figure 2. Schematic showing vertical temperature profile at the edge of the Bill of Portland Island tidal pool on 11 March 2008.

the beginning of the campaign and then kept open by removing the $10-20 \mathrm{~cm}$ of ice that reformed twice daily with an axe. Frost flowers were collected between 4 and $16 \mathrm{~h}$ after the hole had been opened. To estimate time elapsed since formation, which often began overnight, we subtracted $2 \mathrm{~h}$ from the time between the hole being cleared of ice and the time of observation.

[21] Air temperatures during the collection period (213 March 2008) varied between $-10^{\circ} \mathrm{C}$ and $-35^{\circ} \mathrm{C}$ and the average mean temperature of the days on which we collected frost flowers was $-24^{\circ} \mathrm{C}$. Wind ranged from 0 to $13 \mathrm{~m} \mathrm{~s}^{-1}$ and was typically from the east or northwest. Relative humidity was typically over $75 \%$. While diamond dust was common, only one heavy snowfall took place during this period, and frost flowers were affected primarily by blowing snow rather than by precipitation. Other aspects of our environmental conditions were often very similar to those present during Perovich and Richter-Menge's observations in 1994: air temperatures between $-25^{\circ} \mathrm{C}$ and $-15^{\circ} \mathrm{C}$, light winds, high relative humidity $(85-95 \%)$. Temperatures at the surface of the ice were warmer than the air temperature recorded at $1 \mathrm{~m}$ above the ice, and temperature difference varied with ice thickness, snow cover, and sunlight. For example, on 9 March, the air temperature was $-20.1^{\circ} \mathrm{C}$, the temperature at the surface of the snow was $-18.7^{\circ} \mathrm{C}$, and the temperature under $3 \mathrm{~cm}$ of snow, on the ice, was $-15.9^{\circ} \mathrm{C}$. An example of the temperature profile with depth is shown in Figure 2.

[22] Frost flower micrographs were taken in situ with a Dinoscope digital microscope, which provided a range of magnification of 0 to $200 \mathrm{X}$ but required connection to a laptop. This limited its use at frost flower fields far from shore because of the effect of the cold weather on the equipment. Frost flowers were collected with a stainless steel spatula, with care taken to collect samples free of snow or brine. All frost flower samples were dry such that they were incapable of sticking to each other, and no ascertain- able wind-blown snow was collected with them. They were placed in precleaned $15 \mathrm{ml}$ polytetrafluoroethylene (PTFE) sample jars and stored in liquid nitrogen within $2 \mathrm{~h}$. Samples collected at the tidal pools were immersed in liquid nitrogen immediately, in dewars taken to the site on snowmobiles. This involved a lot of spillage, but the remaining liquid nitrogen bath did partially cushion the frost flowers from the jarring nature of snowmobile travel. Some samples that were transported long distances across the bay by snowmobile were noticeably compacted upon arrival at the research station. Settling, estimated by eye on the samples in the PTFE jars just before they were tipped into the sample container as $<10,25$, or $50 \%$, was correlated with the SSA as measured. Hence, estimated settling is noted in Table 2; it should be taken into account when analyzing results, although settling does not necessarily imply metamorphosis.

[23] Snow, ice, and water were also sampled at most locations, as well as the brine around the crack and tidal pool frost flowers. The ice that formed in the test holes was dry or nearly dry on top, and no brine was collected there.

[24] We collected seawater by plunging a container $10 \mathrm{~cm}$ deep into the water. Water was collected from the $1 \mathrm{~m}^{2}$ test holes after the hole had been cleared of the ice formed overnight and the associated chips of floating ice, and the exposed water was well mixed. Water collected from below cores was gathered after the core had been removed and the water had rushed up the hole and then fallen back. We believe this water was similarly well mixed by the turbulence it experienced. A comparison of water collected from the test hole and water collected from a nearby coring hole revealed salinity differences of less than 0.6 psu and differences in the concentrations of major ions $\left(\mathrm{Cl}^{-}, \mathrm{SO}_{4}^{2-}, \mathrm{Na}^{+}\right.$, and $\mathrm{Mg}^{2+}$ ) of less than $8 \%$ (Table 1 ). It is possible that both contained very small ice crystals produced during the removal of the ice. The bromide concentration in the diluted samples was below the detection limit in the first two tests.

Table 1. Concentration of Major Ions and Bromide in Local Seawater Collected From Test Holes and the Coring Hole $50 \mathrm{~m}$ From Shore ${ }^{\mathrm{a}}$

\begin{tabular}{|c|c|c|c|c|c|c|c|}
\hline & $\begin{array}{c}\text { Temperature } \\
\left({ }^{\circ} \mathrm{C}\right)\end{array}$ & $\begin{array}{c}\text { Salinity } \\
\text { (psu) }\end{array}$ & $\begin{array}{c}\mathrm{Cl}^{-} \\
\text {(ppmm) }\end{array}$ & $\begin{array}{c}\mathrm{SO}_{4}^{2-} \\
(\mathrm{ppmm})\end{array}$ & $\begin{array}{c}\mathrm{Br}^{-} \\
(\mathrm{ppmm})\end{array}$ & $\begin{array}{c}\mathrm{Na}^{+} \\
\text {(ppmm) }\end{array}$ & $\begin{array}{l}\mathrm{Mg}^{2+} \\
(\mathrm{ppmm})\end{array}$ \\
\hline 23 February test hole & -14.3 & 5.8 & 2739 & 389 & & 1649 & 218 \\
\hline 25 February test hole & -20.7 & 5.9 & 2801 & 381 & & 1638 & 230 \\
\hline 3 March under core & -21.5 & 5.3 & 2903 & 394 & 8 & 1639 & 201 \\
\hline Standard deviation/average & & $0.3 / 5.7(6 \%)$ & $83 / 2814(3 \%)$ & $6 / 388(2 \%)$ & & $6 / 1642(0.4 \%)$ & $15 / 216(7 \%)$ \\
\hline
\end{tabular}

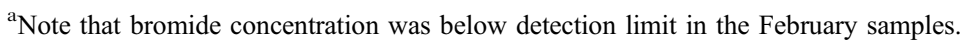




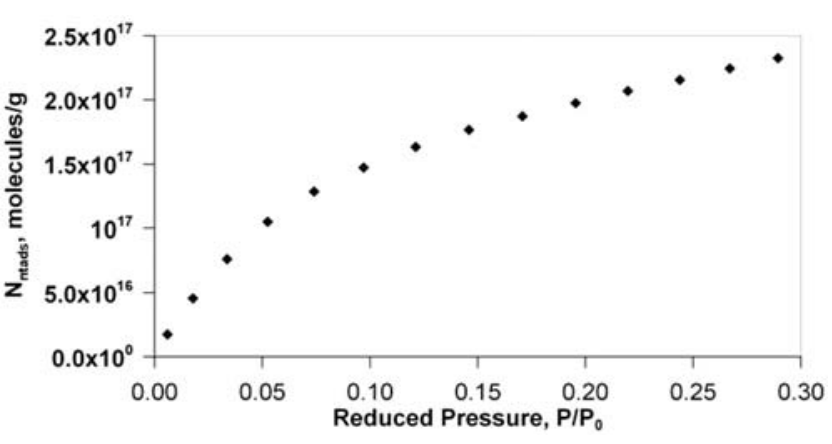

Figure 3. Adsorption isotherm of $\mathrm{CH}_{4}$ on frost flowers collected on 13 March 2008 from the tidal pool at North Maver Island. The number of molecules adsorbed per gram of snow, $N_{\text {ntads }}$, is plotted as a function of reduced pressure, the ratio $P / P_{0}$, where $P$ is the pressure around the sample and $P_{0}$ is the saturated vapor pressure of $\mathrm{CH}_{4}$ at $77 \mathrm{~K}$.

Hence, we have used the ion concentrations from the third for frost flower chemistry comparisons.

[25] In their work, Alvarez-Aviles et al. [2008] collected seawater samples that were found to differ significantly from standard seawater in salinity and ion fractionation. They define them as "sea-ice processed seawater" and explain the differences as resulting from fractionation and the possibility of collecting small ice crystals with their sample [Alvarez-Aviles et al., 2008]. Our Hudson Bay water samples were entirely reasonable compared to under ice isohalines in the area [Ingram and Larouche, 1987] as well as being internally consistent. So we do not believe that sea ice processing took place with our sampling procedure.

\subsection{Surface Area Measurement}

[26] The SSA of frost flowers was measured in Kuujjuarapik, Quebec, using methane adsorption at $77 \mathrm{~K}$, as in the work by Dominé et al. [2005], with an apparatus built at the British Antarctic Survey. The SSA apparatus is similar to that described by Legagneux et al. [2002] and Dominé et al. [2005] and is essentially a manifold made of 0.5 inch and 0.25 inch stainless steel tubing and Swagelok fittings. There are two gas sources: research grade helium $(99.9995 \%$ purity) for assessing the dead volume of the sample container around the frost flower sample, and research grade methane ( $99.995 \%$ purity) to measure the pressure changes due to incremental gas adsorption on the sample surface. The turbomolecular pump is capable of evacuating the system to $4 \times 10^{-5} \mathrm{~Pa}$, and the pressure is measured with a $0-1300 \mathrm{~Pa}$ absolute pressure transducer with resolution and accuracy of $\pm 0.13 \mathrm{~Pa}$. Heating tape is wrapped around the sample container tubing where it exits the liquid nitrogen bath, in order to constrain the distance over which the temperature gradient exists between the $77 \mathrm{~K}$ sample container, and the room temperature of approximately $23^{\circ} \mathrm{C}$. Because the ideal gas law is used to calculate very small variations in pressure in the manifold and sample container, temperature stability is key. The manometer (MKS Baratron 627 ) is insulated and controls its temperature at $45^{\circ} \mathrm{C}$, thereby maintaining constant calibration. Temperatures along the length of the $1 \mathrm{~m}$ tall manifold were measured to establish a baseline for system behavior. Establishing the volumes of the sample container and the various parts of the manifold, and the temperature gradient at the bottom, above the liquid nitrogen, and at the top near the manometer, and recognizing the temperature gradient in the analysis were critical for obtaining sensible and reproducible results. The estimated volumes at their various temperatures, including the volume in the heated part of the manometer, were reduced to the volume of the sample container by multiplying by $77 / \mathrm{T}$ in the usual way.

[27] Approximately $6 \mathrm{~g}$ of frost flower sample (2 jars) were required for each test, in order to have a large enough surface area to measure the pressure difference due to adsorption. Our samples ranged from 5 to $8 \mathrm{~g}$, and there was no correlation between sample size and SSA measured. Working out of doors behind the research station, the frost flowers were carefully transferred from the sample jars to the sample container. The lid of the sample container was attached using a copper gasket and six bolts, and the sealed container was lowered into a $2 \mathrm{~L}$ dewar of liquid nitrogen. It was then carried indoors and attached to the running SSA measurement apparatus using a spring-loaded Swagelok fitting. The sample was allowed to equilibrate at 1 atm for $20 \mathrm{~min}$ before the lowest valve on the manifold was very slowly opened and the sample container was pumped down. This allows the vapor and frost flowers in the cooling sample container to come to equilibrium before being exposed to the temperature gradient in the tubing above the valve. This prevents the formation of microdroplets of amorphous ice on the sample and container walls [Legagneux et al., 2002].

[28] The dead volume around the sample in the sample container was measured by introducing helium gas into the manifold $\left(V_{i}\right)$ to achieve a pressure of $1220-1260 \mathrm{~Pa}$, then opening the lower valve to the expansion volume $\left(V_{e}\right)$ containing the sample and recording the pressure. After this had been done at least six times, or until reproducible results were obtained, the helium was evacuated. To obtain SSA, methane, which can be adsorbed on ice [Legagneux et al., 2002], was introduced in a sequence of 14 increments, from 47 to $470 \mathrm{~Pa}$. A BET analysis was used to determine surface area of the ice [Brunauer et al., 1940] whose principle is described in detail by Legagneux et al. [2002]. An adsorption isotherm is plotted, such as the one shown in Figure 3. It is shape classified as a type II isotherm [Brunauer et al., 1940] and can be analyzed as outlined by Brunauer et al. [1938]. The slope and intercept of a function, $Y=f\left(P_{\mathrm{CH} 4} /\right.$ $P_{0}$ ), of the chamber pressure, $P_{\mathrm{CH} 4}$, relative to the saturating vapor pressure of methane at $77 \mathrm{~K}, P_{0}(1294 \mathrm{~Pa})$ yield the surface area of the sample occupied by a monolayer of methane molecules, which have a cross-sectional area of $\sigma_{m}=1.918 \times 10^{-19} \mathrm{~m}^{2}$ [Chaix et al., 1996]. In the analysis, the net heat of adsorption of methane on snow $\Delta Q_{\mathrm{CH} 4 \text {,snow }}$ is also derived from the slope and intercept of the linear function $Y=f\left(P_{\mathrm{CH} 4} / P_{0}\right)$ and can be used to assess the reliability of the surface area measurement [Dominé et al., 2000]. Acceptance of an incorrect $\Delta Q_{\mathrm{CH} 4 \text {,snow produces }}$ errors in surface area, and thus agreement on $\Delta Q_{\mathrm{CH} 4 \text {, snow }}$ is critical for comparisons of SSA from different researchers. Experimentally determined values of $\Delta Q_{\mathrm{CH} 4}$ have ranged from $1919 \pm 35 \mathrm{~J} \mathrm{~mol}^{-1}$ [Chaix et al., 1996], $2195 \mathrm{~J} \mathrm{~mol}^{-1}$ [Hanot and Dominé, 1999], $2100 \pm 150 \mathrm{~J} \mathrm{~mol}^{-1}$ [Dominé et al., 2000], and $2240 \pm 200 \mathrm{~J} \mathrm{~mol}^{-1}$ [Legagneux et al., 2002] 
Table 2. Frost Flower SSA Results ${ }^{\mathrm{a}}$

\begin{tabular}{|c|c|c|c|c|c|c|c|c|}
\hline \multirow[b]{2}{*}{ Date } & \multicolumn{2}{|c|}{ Collection } & \multirow[b]{2}{*}{$\begin{array}{c}T_{\text {Formation }} \\
\left({ }^{\circ} \mathrm{C}\right)\end{array}$} & \multirow[b]{2}{*}{$\begin{array}{l}\text { Settling } \\
(\%)\end{array}$} & \multirow[b]{2}{*}{$\begin{array}{l}\text { Weight } \\
(\mathrm{g})\end{array}$} & \multirow[b]{2}{*}{$\begin{array}{c}\Delta Q_{\mathrm{CH} 4, \text { snow }} \\
\left(\mathrm{J} \mathrm{mol}^{-1}\right)\end{array}$} & \multirow[b]{2}{*}{$\begin{array}{c}\text { SSA } \\
\left(\mathrm{cm}^{2} \mathrm{~g}^{-1}\right)\end{array}$} & \multirow[b]{2}{*}{$\begin{array}{c}\text { Standard Deviation } \\
\text { Divided by Average (\%) }\end{array}$} \\
\hline & Location & $\begin{array}{c}\text { Temperature } \\
\left({ }^{\circ} \mathrm{C}\right)\end{array}$ & & & & & & \\
\hline 2 March 2008 & test hole & -20.3 & -24.6 & $<10$ & 6.11 & 2092 & 141 & 9 \\
\hline 2 March 2008 & test hole & -20.3 & -24.6 & $<10$ & 6.11 & 2593 & 158 & 9 \\
\hline 2 March 2008 & test hole & -20.3 & -24.6 & $<10$ & 6.11 & 2488 & 168 & 9 \\
\hline 6 March 2008 & test hole & -26.5 & -22.6 & $<10$ & 5.36 & 2554 & 63 & 4 \\
\hline 6 March 2008 & test hole & -26.5 & -22.6 & $<10$ & 5.36 & 2625 & 67 & 4 \\
\hline 6 March 2008 & test hole & -26.5 & -22.6 & $<10$ & 4.76 & 2614 & 152 & 4 \\
\hline 6 March 2008 & test hole & -26.5 & -22.6 & $<10$ & 4.76 & 2289 & 143 & 4 \\
\hline 8 March 2008 & test hole & -21.0 & -25.5 & $<10$ & 6.66 & 2454 & 299 & 8 \\
\hline 8 March 2008 & test hole & -21.0 & -25.5 & $<10$ & 6.66 & 2166 & 268 & 8 \\
\hline 5 March 2008 & crack & -17.0 & -19.8 & 50 & 8.02 & 2397 & 103 & 7 \\
\hline 5 March 2008 & crack & -17.0 & -19.8 & 50 & 7.50 & 2328 & 80 & 7 \\
\hline 5 March 2008 & crack & -17.0 & -19.8 & 50 & 7.50 & 2538 & 85 & 7 \\
\hline 6 March 2008 & crack & -22.9 & -25.5 & 50 & 6.96 & 2424 & 146 & 4 \\
\hline 6 March 2008 & crack & -22.9 & -25.5 & 50 & 6.96 & 2548 & 154 & 4 \\
\hline 6 March 2008 & crack & -22.9 & -25.5 & 50 & 6.96 & 2418 & 160 & 4 \\
\hline 9 March 2008 & crack & -20.1 & -26.3 & $<10$ & 4.82 & 2607 & 201 & 7 \\
\hline 9 March 2008 & crack & -20.1 & -26.3 & $<10$ & 4.82 & 2598 & 197 & 7 \\
\hline 9 March 2008 & crack & -20.1 & -26.3 & $<10$ & 4.82 & 2675 & 223 & 7 \\
\hline 12 March 2008 & tidal & -22.6 & -23.4 & $<10$ & 7.72 & 2694 & 152 & 7 \\
\hline 12 March 2008 & tidal & -22.6 & -23.4 & $<10$ & 7.72 & 2435 & 168 & 7 \\
\hline 13 March 2008 & tidal & -12.7 & -27.0 & 25 & 8.64 & 2441 & 224 & 1 \\
\hline 13 March 2008 & tidal & -12.7 & -27.0 & 25 & 8.64 & 2593 & 221 & 1 \\
\hline
\end{tabular}

${ }^{\mathrm{a}}$ Frost flowers were so dry that they were incapable of sticking to each other, and no ascertainable wind-blown snow was collected with them. The tidal frost flowers come from the tidal pool at North Maver Island. Where weight is repeated for a given date, that sample was tested two or three times, yielding the reproducibility shown in the last column. Temperature at the time of collection and at the time of formation (see text) comes from the Environment Canada Met Office online data. Settling refers to sample settling during transport as an estimated percentage of the original volume, but the SSA results are those measured, i.e., with no compensation for estimated settling.

to $2450 \pm 200 \mathrm{~J} \mathrm{~mol}^{-1}$ [Dominé et al., 2005]. This last value was associated with the discovery of the influence of methane adsorption on the walls of the stainless steel (ss) sample container, $\Delta Q_{\mathrm{CH} 4, \mathrm{ss}}=1300 \mathrm{~J} \mathrm{~mol}^{-1}$. Not taking this contribution into account produces deceptively low values of $\Delta Q_{\mathrm{CH} 4 \text {,snow, }}$ particularly for samples with low surface area [Dominé et al., 2005]. Our data analysis and the results shown in Table 2 include this correction.

[29] We selected experimental conditions and a $P_{\mathrm{CH} 4} / P_{0}$ range on the basis of a series of reproducible experiments that produce a $\Delta Q_{\mathrm{CH} 4 \text {,snow }}$ value of $2450 \pm 200$ [Dominé et al., 2005] and applied those conditions across all experiments. With respect to the method described in detail by Legagneux et al. [2002], we optimized the ratio $V_{i} / V_{e}$ to 0.86 by adjusting the size of the manifold (introductory volume) and sample containers (expansion volume) to $68.3 \mathrm{~cm}^{3}$ and $71.5 \mathrm{~cm}^{3}$, respectively. Further, the success of this SSA measurement technique depends on selecting the linear range of the function $Y=f\left(P_{\mathrm{CH} 4} / P_{0}\right)$, selected by seeking the optimum correlation coefficient of the least squares fit for $Y=f\left(P_{\mathrm{CH} 4} / P_{0}\right)$ [Legagneux et al., 2002], as 0.07 to 0.22 . We adopted this same range because it produced the best fit for the BET transform and allows us to compare our SSA results to theirs. Legagneux et al. [2002] also recommend always using the same number of points within this range to permit comparisons of relative SSA. We chose 7 points because in some cases when we used 8 points, the linearity suffered and it affected the $\Delta Q_{\mathrm{CH} 4 \text {,snow }}$ value obtained.

[30] We measured the SSA of 10 frost flower samples (each two PTFE jars full) from 8 separate sampling expeditions. We tested each sample two or three times to establish reproducibility of the SSA and $\Delta Q_{\mathrm{CH} 4 \text {,snow }}$ values obtained, by evacuating the sample container after one run and repeating the experiment. The potential error inherent in the experimental method is $5 \%$. This was determined by varying temperature and pressure values in real data sets by their instrument accuracy $\left(0.13 \mathrm{~Pa}\right.$ and of $\left.0.1{ }^{\circ} \mathrm{C}\right)$ and assessing the change in the resulting SSA and $\Delta Q_{\mathrm{CH} 4}$. We also tested reproducibility across samples from a given location. Results are presented in section 3.

[31] Other authors have used the term total surface area (TSA) to describe frost flower surface area per area of sea ice [Dominé et al., 2002], renamed snow area index (SAI) by Taillandier et al. [2006], by analogy to leaf area index:

$$
\mathrm{SAI}=\mathrm{SSA} \times\left(\mathrm{WA}_{\mathrm{FF}}\right)
$$

where $\mathrm{WA}_{\mathrm{FF}}$ is the weight of frost flowers per unit area of sea ice. The surface area amplification is then $(\mathrm{SAI}+1)$. To determine SAI, we marked off squares of $232 \mathrm{~cm}^{2}$ (6 inches $(1$ inch $=2.54 \mathrm{~cm})$ on a side $)$ on the sea ice surface and collected all of the frost flowers in each into a separate sample jar and weighed. We estimated areal coverage by opening the digital images in a graphic analysis software, applying a threshold and filtering out the darker ice and sea ice surface shadowed by the frost flowers.

\subsection{Chemical Analysis}

[32] Melted frost flower samples were diluted by a factor of $10^{3}$ with ultra high purity water $(18 \mathrm{M} \Omega)$ and analyzed for ion concentrations in a Dionex DX500 ion chromatograph with a $4 \mathrm{~mm}$ AS18 separator column for anions and a $3 \mathrm{~mm}$ CS12A-5 $\mu \mathrm{m}$ separator column for cations. Simultaneous injection of the samples was performed using an AS autosampler which is equipped with a $500 \mu 1$ loop for the anions and a $250 \mu \mathrm{l}$ loop for the cations. We used isocratic elution with $22 \mathrm{mM}$ potassium hydroxide for the anions and $20 \mathrm{mM}$ methane sulphonic acid for the cations. Both runs 

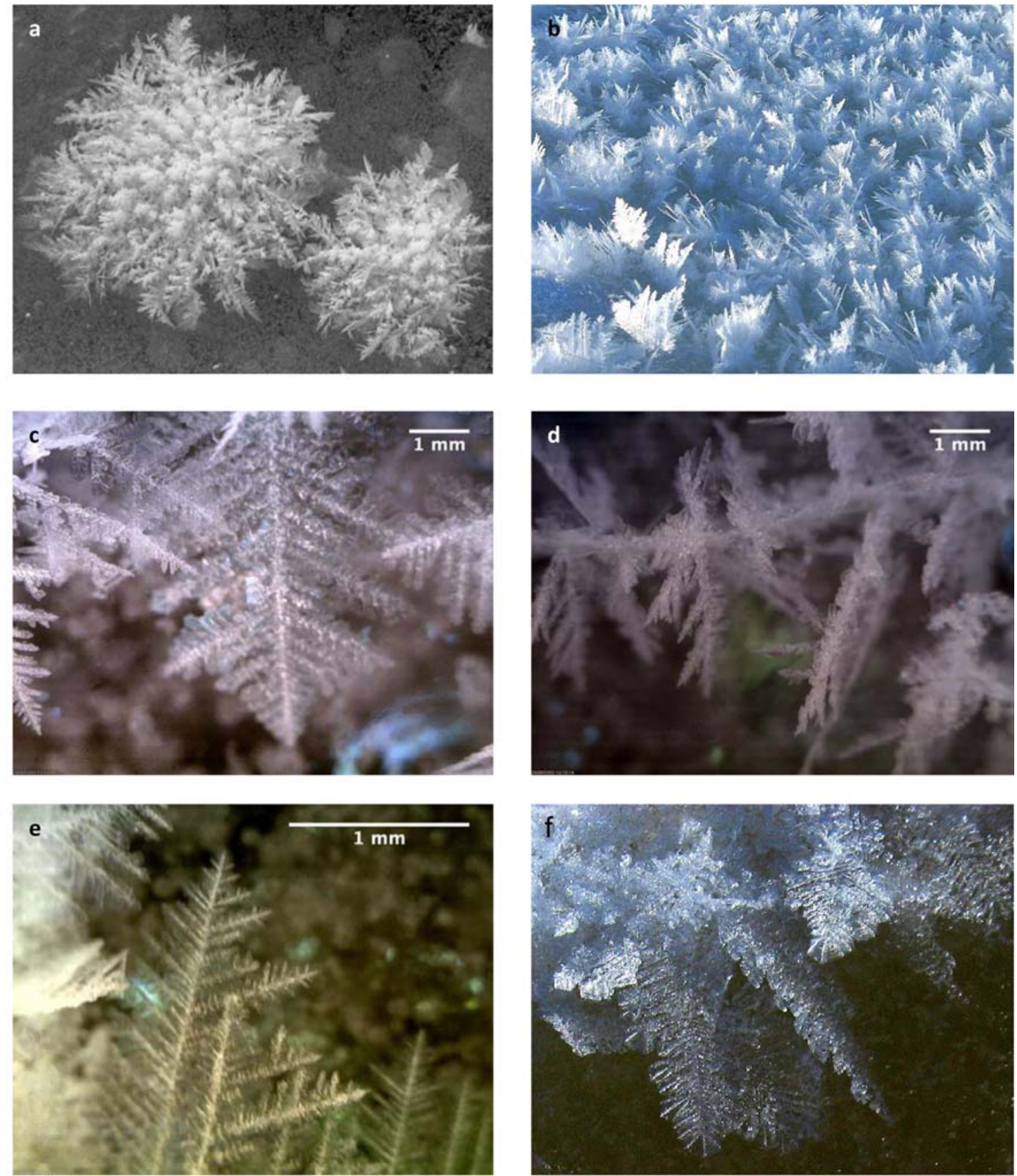

Figure 4. Dendritic frost flowers: (a) test hole, 2 March $2008,-29^{\circ} \mathrm{C}$, width of largest initial "chrysanthemum" shown is $\sim 10 \mathrm{~cm}$; (b) tidal pool, 11 March 2008, $-24^{\circ} \mathrm{C}$; (c-e) test hole, 2 March 2008, $-29^{\circ} \mathrm{C}$; (f) tidal pool, 13 March $2008,-27^{\circ} \mathrm{C}$ (frost flowers approximately $2 \mathrm{~cm}$ long).

were 16 min long. Flow rates were 1.0 and $0.5 \mathrm{ml} \mathrm{min}^{-1}$ for the anions and cations, respectively. The accuracy of ion concentration data is $\pm 5 \%$ except in the case of very low, neardetection-limit ion concentrations such as bromide, which may have uncertainties of $\pm 10 \%$. Frost flower salinity was calculated as the sum of the concentrations of major (measured) ions: $\mathrm{Cl}^{-}, \mathrm{SO}_{4}^{2-}, \mathrm{NO}_{3}^{-}, \mathrm{Br}^{-}, \mathrm{Na}^{+}, \mathrm{K}^{+}, \mathrm{Mg}^{2+}$, and $\mathrm{Ca}^{+}$.

[33] Water salinity was also measured with a Hach sensION5 ISFET conductivity meter with internal temperature correction. This device has a resolution of $0.1 \mathrm{~g} \mathrm{l}^{-1}$ and accuracy of $\pm 0.1 \mathrm{psu}$ between -2.0 and $35.0^{\circ} \mathrm{C}$. Salinity values obtained this way were similar to those calculated using ion chromatography: 5.3 psu for nearshore water and 21.1 psu for water (taken from under a core) from the bay outside of the Bill of Portland Island.

\section{Results}

\subsection{Frost Flower Observations}

[34] The frost flowers on test holes began as tiny tufts on the newly formed sea ice, about $2 \mathrm{~h}$ after the hole was opened. These grew to round clumps (Figure 4a), which then spread until they completely covered the test hole over a period of about $16 \mathrm{~h}$. The surface of the ice where they 

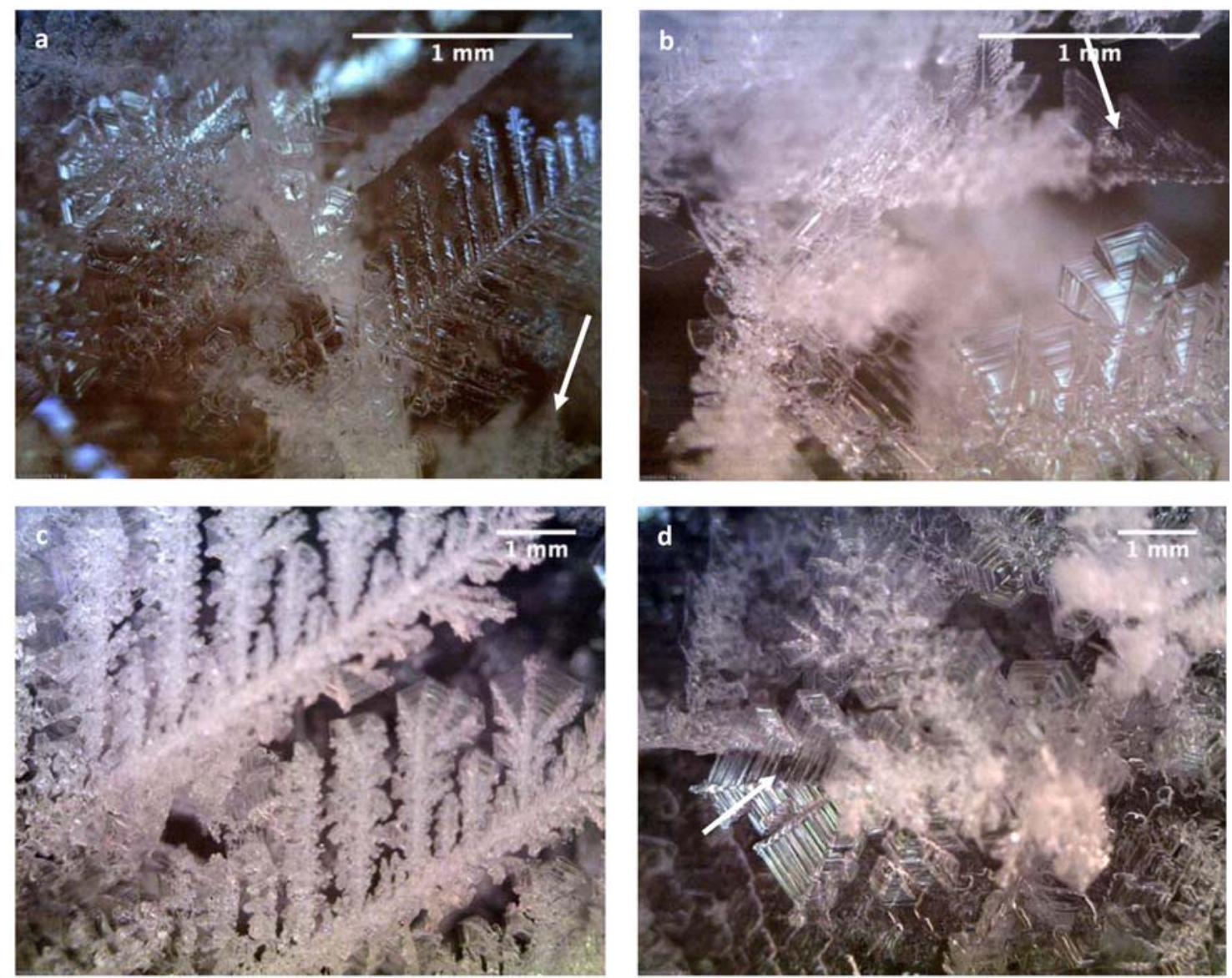

Figure 5. (a) Broad branch and (b) sector plate-like frost flowers, from test hole, 2 March 2008, photographed at $-29^{\circ} \mathrm{C}$ but formed at $-25^{\circ} \mathrm{C}$. Note the 10 to $50 \mu \mathrm{m}$ wavelength roughness on the sector plates in Figure 5b (arrow). (c and d) Test hole frost flowers, photographed 27 February 2008, at 1230 LT, photographed at $-25^{\circ} \mathrm{C}$ but formed at air temperature of -29 to $-36^{\circ} \mathrm{C}$. In Figure $5 \mathrm{c}$ note the plates growing between the original dendritic branches. In Figure 5d note the cross ribs (arrow), described for snow by Nelson [2005].

grew was relatively dry, such that even a piece of filter paper laid on it would not become wet. The frost flowers found in the crack and on tidal pools appeared fernlike (Figure 4b). They generally stood in or near water and were wet at the base. Those in the crack were sheltered from the wind by the walls of the crack, which were at least $10 \mathrm{~cm}$ high. Those on the tidal pools were unsheltered. The largest tidal pool, off the Bill of Portland Island, was approximately $10 \mathrm{~m}$ wide by $60 \mathrm{~m}$ long. The smaller tidal pools off the Maver Islands were about $3 \mathrm{~m}$ wide by $5 \mathrm{~m}$ long.

[35] Frost flower crystal shape may be described using terms defined for secondary snow habit by Nelson [2005]. While primary habit refers simply to aspect ratio, and is, depending on temperature and surface supersaturation, either tabular or columnar, secondary characteristics such as branching and tip shape are determined by the temperature, supersaturation relative to ice, vapor mean free path, and time [Nelson, 2001]. Most frost flowers we observed were dendritic, although within this classification, some were fernlike, with a high density of side branches (Figures $4 \mathrm{c}$ and $4 \mathrm{e}$ ), while others were broad branch (Figure 5a), stellar, or resembled sector plates (Figure $5 \mathrm{~b}$ ). All of these had grown at air temperatures of between -24 and $-36^{\circ} \mathrm{C}$, but near-ice temperatures would have been warmer. This is particularly true at the crack and tidal pools, where regular flooding would have contributed to warmer temperatures and greater ambient supersaturation relative to ice.

[36] These crystal habits are generally consistent with published descriptions of the temperature regimes of hexagonal plates, sector plates, and stellar dendrites in snow between -8 and $-25^{\circ} \mathrm{C}$ [Mason, 1992; Martin et al., 1996]. They illustrate the variations that are found, the development of which is described in detail by Hallett and Mason [1958], Mason [1992], and Nelson [2005]. Observations of crystal habit changes that occur with temperature and degree of supersaturation are considered evidence of step nucleation as the primary growth mechanism in snow [Hallett and Mason, 1958; Knight, 1972; Nelson, 2001] and of the macro step model of branch growth [Nelson, 2001]. Similar arguments may also be made for frost flowers growing by step nucleation, wherein growth occurs by the sequential addition of atoms to a structure, into positions dictated by minimization of interface energy. Our observations support this. Note the $10-50 \mu \mathrm{m}$ wavelength ripples, or successive branch perimeters, in Figure 5b, the plates developing between branches in Figure $5 \mathrm{c}$, and the cross ribs in 

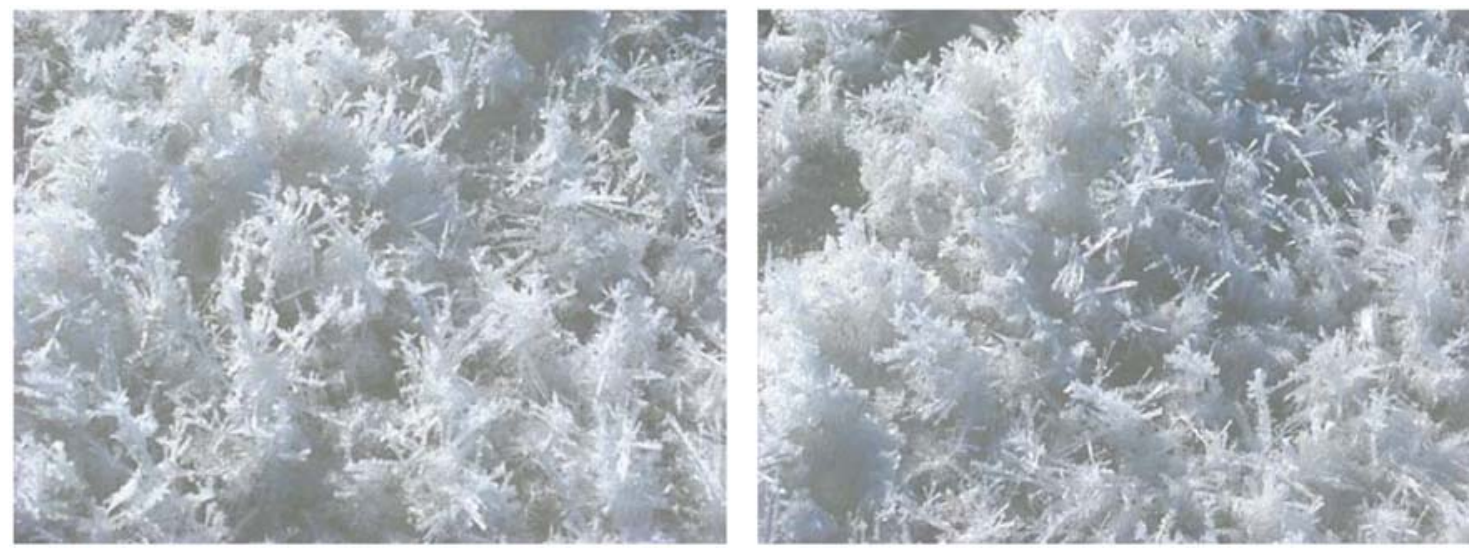

Figure 6. Needle-like frost flowers, 12 March 2008, North Maver Island tidal pool, $-23^{\circ} \mathrm{C}$.

Figure $5 \mathrm{~d}$. These surface irregularities are most likely caused by variations in temperature and supersaturation of the near surface environment during growth and illustrate the stepwise development of frost flowers.

[37] Warmer temperatures lead to slower growth and wider crystal tips [Nelson, 2005], which may have caused the broad branches seen in Figures $4 \mathrm{a}$ and $4 \mathrm{~b}$ and the weblike structures between branch tips seen in Figure 4c. Needles are formed by layer nucleation on the basal face, when critical supersaturation there is less than that on the prism face; they are generally found between -3 and $-8^{\circ} \mathrm{C}$ and at relatively low supersaturation [Nelson, 2005]. The needles seen in Figure 6 were found on tidal pool ice at air temperatures of $-23^{\circ} \mathrm{C}$, but again, the near surface temperature at this tidal location would have been warmer than the measured air temperature.

[38] Like others, we noted the macroscopic rigidity of frost flowers [Dominé et al., 2005; Alvarez-Aviles et al., 2008]. No mechanical breakage of frost flowers by wind was observed during our field work, even in winds of up to $6 \mathrm{~m} \mathrm{~s}^{-1}$. Frost flowers fluttered in the wind but rarely broke and did not blow away. The morning after a snowstorm that saw wind speeds of $7-13 \mathrm{~m} \mathrm{~s}^{-1}$, previously formed frost flowers that had grown on the windward side of the Bill of Portland Island tidal pool were found broken off at their base and scattered mostly intact on the surrounding snow (Figure 7a). This is an important new observation, as we had expected that such fragments would be widely dissipated. Frost flowers toward the center and the leeward side of the tidal pool, however, appeared unbroken, though it is possible that small fragments from their tips had broken off and been lofted. At the same time, newer frost flowers on the windward side of a tidal pool off the Maver Islands were found all leaning away from the wind direction (Figure 7b). Again, frost flowers on the leeward side of the pool appeared unbroken, with the same caveat as above.

[39] We also noted that the threshold for mobilization of blowing snow is lower than that for frost flower breakage. During a period in which there was no new precipitation, we observed frost flowers collecting (Figure 7c) or even becoming covered with blowing snow, and small snow banks forming against frost flowers (Figure 7d). Although high winds could be observed at the surface of the sea ice from the blowing snow, broken and snow covered frost flowers were observed only on the windward side of frost flower fields; those on the leeward side were apparently sheltered.

\subsection{Frost Flower Surface Area}

[40] We ran 22 tests on 10 samples of frost flowers, the results are shown in Table 2. SSA values ranged between 63 and $299 \mathrm{~cm}^{2} \mathrm{~g}^{-1}$ with a mean of $162 \mathrm{~cm}^{2} \mathrm{~g}^{-1}$. These values are similar to those obtained by Dominé et al. [2005] on test hole frost flowers from the Arctic Ocean near Barrow, Alaska, of $185(+80-50) \mathrm{cm}^{2} \mathrm{~g}^{-1}$. Our field frost flower SSA measurements had reproducibilities ranging from $1 \%$ to $9 \%$ and averaging $5 \%$.

[41] The mean $\Delta Q_{\mathrm{CH} 4 \text {,snow }}$ obtained was $2480 \mathrm{~J} \mathrm{~mol}^{-1}$ with a standard deviation of $157 \mathrm{~J} \mathrm{~mol}^{-1}(6 \%)$. This low standard deviation supports the $P / P_{0}$ range chosen and mathematical accommodation of temperature gradients. In two separate tests at the Bill of Portland and Maver Island tidal pools (12 and 13 March), we found coverage of 75 and $90 \%$ and SAI of 1.76 and $2.14 \mathrm{~m}^{2} \mathrm{~m}^{-2}$ of sea ice, respectively.

\subsection{Frost Flower, Brine, and Source Water Chemistry}

[42] The salinity of frost flowers samples and the local water, and the enrichment $\left(E_{f}\right)$ of the former relative to the latter, are shown in Table 3. Test hole frost flowers had significant salinity enrichment, by a factor of 2.7 on 2 March and 1.7 on 8 March, despite the low water salinity at the nearshore location and the lack of surface skim on the ice that formed on the test holes. The source of this excess frost flower salinity must therefore be brine channels. In contrast, frost flowers found in tidal pools and cracks were in most cases salinity depleted compared to their source water. This is due to the periodic renewal of source water via the tide, which mixes with surface snow and is diluted.

[43] Ion concentrations in frost flowers and related water are shown in Table 4. Note the significantly higher ion concentrations in water from west of the Bill of Portland Island (main bay water 063W2) than in the nearshore water.

\subsection{Frost Flower Chemistry and Enrichment as a Function of Time and Temperature}

[44] Table 5 includes ion ratios and enrichment factors for certain ions in frost flowers and related water. We took the approach used by Alvarez-Aviles et al. [2008] of using $\mathrm{Cl}^{-}$ 

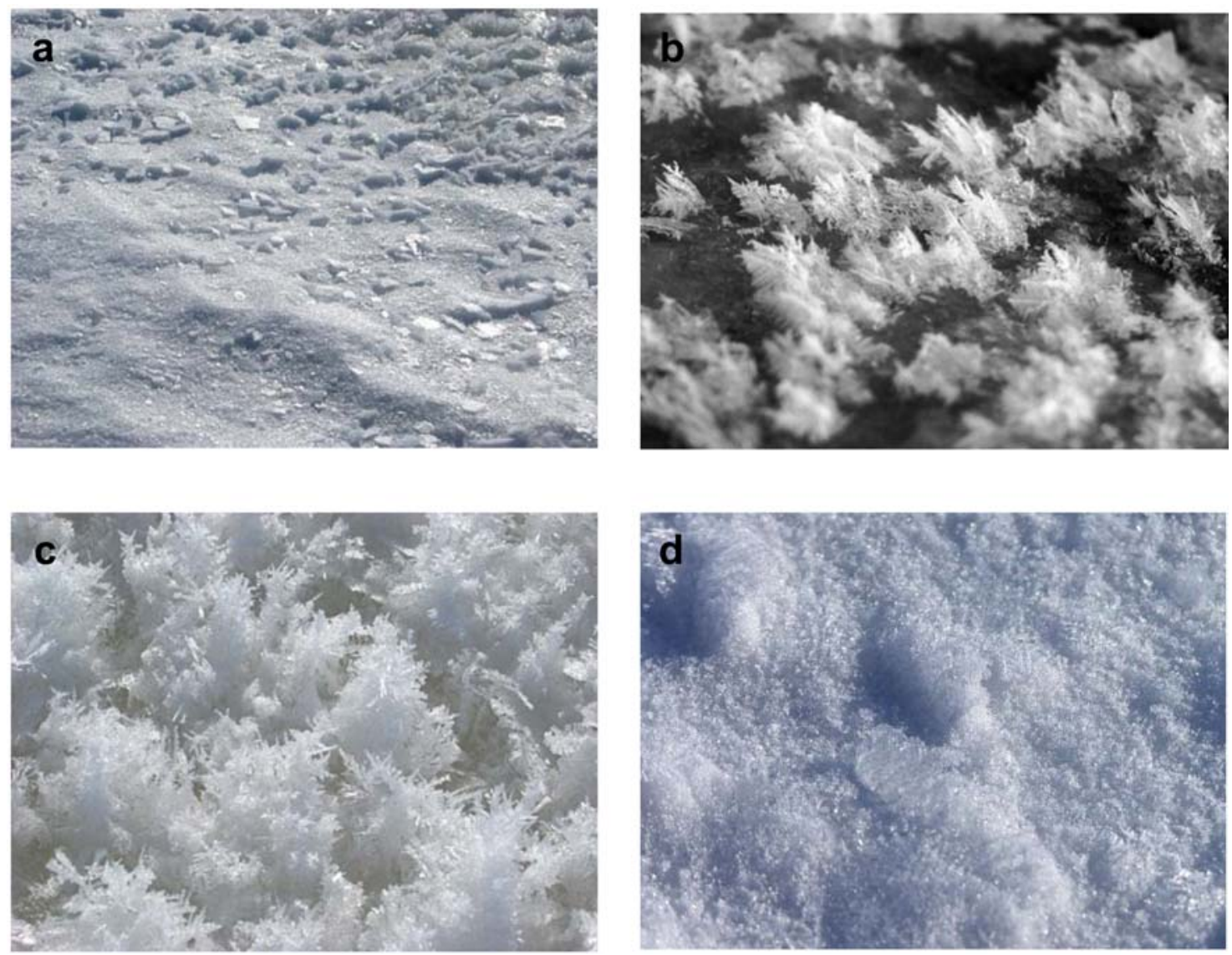

Figure 7. Tidal pool frost flowers showing wind's effect: (a) broken, 11 March 2009, temperature $-24^{\circ} \mathrm{C}$, wind $7-13 \mathrm{~m} \mathrm{~s}^{-1}$; (b) leaning away from the wind, 11 March 2009 , temperature $-24^{\circ} \mathrm{C}$, wind $7-13 \mathrm{~m} \mathrm{~s}^{-1}$; (c) dusted with snow, 12 March 2008, temperature $-23^{\circ} \mathrm{C}$, wind $3.6 \mathrm{~m} \mathrm{~s}^{-1}$; (d) catching windblown snow, 11 March 2009, temperature $-24^{\circ} \mathrm{C}$, wind $6 \mathrm{~m} \mathrm{~s}^{-1}$.

as the basis for comparison of concentrations of other ions. For our purposes, chloride makes a better basis for comparison than sodium because while mirabilite $\left(\mathrm{Na}_{2} \mathrm{SO}_{4}\right.$. $\left.10 \mathrm{H}_{2} \mathrm{O}\right)$, begins to form at $-8^{\circ} \mathrm{C}$, hydrohalite $(\mathrm{NaCl}$.
$2 \mathrm{H}_{2} \mathrm{O}$ ) does not precipitate until $-22^{\circ} \mathrm{C}$. Although air temperatures were often just below $-22^{\circ} \mathrm{C}$, the temperature at the surface of the ice would not have been, as discussed in section 3.1. We also believe the enrichment $\left(E_{f}\right)$ factors

Table 3. Salinity for Frost Flowers and Relevant Seawater ${ }^{a}$

\begin{tabular}{|c|c|c|c|c|c|}
\hline Sample Identification & $\begin{array}{c}\text { Collection Air } \\
\text { Temperature }\left({ }^{\circ} \mathrm{C}\right) \\
\end{array}$ & $\begin{array}{c}\text { Formation Air } \\
\text { Temperature }\left({ }^{\circ} \mathrm{C}\right)\end{array}$ & $\begin{array}{l}\text { Growth } \\
\text { Time }(\mathrm{h}) \\
\end{array}$ & $\begin{array}{c}\text { Salinity } \\
(\%)\end{array}$ & $\begin{array}{c}\text { Salinity } \\
\text { Enrichment } E_{f}\end{array}$ \\
\hline Nearshore water, $063 \mathrm{~W} 1$ & -21.5 & & & 5.3 & \\
\hline 020308 test hole FF 4 & -28.7 & -24.6 & 15 & 14.5 & 2.74 \\
\hline 020308 test hole FF 5 & -28.7 & -24.6 & 15 & 14.1 & 2.72 \\
\hline 080308 test hole FF 4 & -21.4 & -25.5 & 26 & 8.8 & 1.66 \\
\hline 080308 test hole FF 5 & -21.4 & -25.5 & 26 & 9.3 & 1.75 \\
\hline Main bay water, $063 \mathrm{~W} 2$ & -21.5 & & & 21.5 & \\
\hline 060308 crack FF L & -21.5 & -25.3 & 8 & 10.0 & 0.47 \\
\hline 090308 crack FF 1 & -26.3 & -27.2 & 8 & 18.9 & 0.88 \\
\hline 110308 tidal FF, Bill of Portland & -25.6 & -21.7 & 10.5 & 13.4 & 0.62 \\
\hline 110308 tidal FF, Bill of Portland & -25.6 & -21.7 & 10.5 & 5.9 & 0.27 \\
\hline 120308 tidal FF, Maver Islands & -23.4 & -23.4 & 2.5 & 19.5 & 0.91 \\
\hline 120308 tidal FF, Maver Islands & -23.4 & -23.4 & 2.5 & 23.4 & 1.09 \\
\hline 120308 tidal FF, Maver Islands & -23.4 & -23.4 & 2.5 & 21.7 & 1.01 \\
\hline 130308 tidal FF, Maver Islands & -14.7 & -27.0 & 13 & 5.1 & 0.24 \\
\hline 130308 tidal FF, Maver Islands & -14.7 & -27.0 & 13 & 11.2 & 0.52 \\
\hline 130308 tidal FF, Maver Islands & -14.7 & -27.0 & 13 & 7.5 & 0.35 \\
\hline 130308 tidal FF, Maver Islands & -14.7 & -27.0 & 13 & 7.7 & 0.36 \\
\hline
\end{tabular}

${ }^{a}$ Salinity enrichment factor $\left(E_{f}\right)$ is frost flower salinity relative to the salinity of the source water (nearshore or main bay). Main bay water (063W2) is from a coring hole made near the crack, west of the Bill of Portland Island. 
Table 4. Formation Air Temperature and Ion Concentrations for Frost Flowers and Relevant Seawater ${ }^{\mathrm{a}}$

\begin{tabular}{|c|c|c|c|c|c|c|c|c|}
\hline Sample Identification & $\begin{array}{c}\text { Formation Air } \\
\text { Temperature (degC) }\end{array}$ & $\begin{array}{c}\mathrm{Cl}^{-} \\
(\mathrm{ppmm})\end{array}$ & $\begin{array}{l}\mathrm{SO}_{4}^{2-} \\
(\mathrm{ppmm})\end{array}$ & $\begin{array}{c}\mathrm{Br}^{-} \\
(\mathrm{ppmm})\end{array}$ & $\begin{array}{c}\mathrm{Na}^{+} \\
(\mathrm{ppmm})\end{array}$ & $\begin{array}{c}\mathrm{K}^{+} \\
(\mathrm{ppmm})\end{array}$ & $\begin{array}{l}\mathrm{Mg}^{2+} \\
(\mathrm{ppmm})\end{array}$ & $\begin{array}{c}\mathrm{Ca}^{2+} \\
(\mathrm{ppmm})\end{array}$ \\
\hline Nearshore water, $063 \mathrm{~W} 1$ & & 2,903 & 394 & 8 & 1,639 & 59 & 201 & 63 \\
\hline 020308 test hole FF 4 & -24.6 & 8,228 & 1,296 & 27 & 3,997 & 174 & 592 & 217 \\
\hline 020308 test hole FF 5 & -24.6 & 8,047 & 1,261 & 26 & 3,904 & 164 & 581 & 146 \\
\hline 080308 test hole FF 4 & -25.5 & 5,033 & 777 & 19 & 2,445 & 105 & 358 & 102 \\
\hline 080308 test hole FF 5 & -25.5 & 5,375 & 737 & 15 & 2,576 & 109 & 391 & 88 \\
\hline Main bay water, $063 \mathrm{~W} 2$ & & 11,490 & 1,573 & 37 & 6,695 & 256 & 1,202 & 257 \\
\hline 060308 crack FF L & -25.3 & 5,878 & 688 & 18 & 2,793 & 127 & 402 & 100 \\
\hline 090308 crack FF 1 & -27.2 & 11,181 & 1,165 & 24 & 5,420 & 215 & 790 & 143 \\
\hline 110308 tidal FF, Bill of Portland & -21.7 & 7,777 & 1,000 & 20 & 3,745 & 164 & 535 & 149 \\
\hline 110308 tidal FF, Bill of Portland & -21.7 & 3,448 & 462 & 9 & 1,643 & 68 & 237 & 72 \\
\hline 120308 tidal FF, Maver Islands & -23.4 & 10,289 & 2,712 & 33 & 5,434 & 182 & 751 & 119 \\
\hline 120308 tidal FF, Maver Islands & -23.4 & 12,912 & 2,591 & 38 & 6,442 & 230 & 912 & 269 \\
\hline 120308 tidal FF, Maver Islands & -23.4 & 11,798 & 2,564 & 37 & 5,992 & 210 & 839 & 248 \\
\hline 130308 tidal FF, Maver Islands & -27.0 & 2,881 & 475 & 9 & 1,404 & 56 & 204 & 61 \\
\hline 130308 tidal FF, Maver Islands & -27.0 & 6,410 & 981 & 20 & 3,134 & 131 & 446 & 84 \\
\hline 130308 tidal FF, Maver Islands & -27.0 & 4,332 & 588 & 13 & 2,074 & 91 & 298 & 97 \\
\hline 130308 tidal FF, Maver Islands & -27.0 & 4,386 & 705 & 14 & 2,148 & 86 & 316 & 57 \\
\hline
\end{tabular}

${ }^{\mathrm{a}}$ For comparison, standard mean ocean water (SMOW) contains the following ions concentrations (ppmm): $\mathrm{Cl}^{-}, 19,350 ; \mathrm{SO}_{4}^{2-}, 2712 ; \mathrm{Na}^{+}, 10,775 ; \mathrm{K}^{+}$, 399; $\mathrm{Mg}^{2+}, 1295$; and $\mathrm{Ca}^{+}, 412$ [Rankin et al., 2000].

should be calculated with respect to local seawater, the source of the frost flowers of interest, and define $E_{f}$ as follows:

$$
E_{f}(X)=\left([X]_{\text {sample }} /\left[\mathrm{Cl}^{-}\right]_{\text {sample }}\right) /\left([X]_{\text {refwater }} /\left[\mathrm{Cl}^{-}\right]_{\text {refwater }}\right),
$$

where $X$ is the ion of interest and refwater refers to the local source water, rather than standard seawater as used by Alvarez-Aviles et al. [2008]. Like the work of Alvarez-Aviles et al. [2008], we interpret the variability in $E_{f}\left(\mathrm{SO}_{4}^{2-}\right)$ at formation air temperatures of $-22^{\circ} \mathrm{C}$ to $-27^{\circ} \mathrm{C}$ as related to mirabilite precipitation, and indeed our data show similar variability in $E_{f}\left(\mathrm{SO}_{4}^{2-}\right)$ with temperature at air temperatures below $-9^{\circ} \mathrm{C}$.

[45] Test hole frost flowers had enrichment factors slightly greater than 1 for both bromide and sulfate, but salinity enrichment was much larger. Crack frost flowers had enrichment factors slightly less than 1 for both bromide and sulfate, and salinity was similarly slightly depleted.
Tidal pool frost flowers collected on 2 of the 3 days were significantly enriched in sulfate. On the other day they were neither enriched nor depleted, within the $7 \%$ accuracy possible when comparing two ion concentrations $(5 \%$ accuracy each). Bromide ion concentrations were so low that only $10 \%$ measurement accuracy can be expected, leading to $12 \%$ accuracy in $E_{f}\left(\mathrm{Br}^{-}\right)$and no consistent enrichment or depletion in frost flowers.

\section{Discussion}

\subsection{Source Water Salinity and Frost Flower Location and Salinity}

[46] The Great Whale River plume produced under-ice salinities in our experimental area of 3 to $21 \mathrm{psu}$, much less than the salinity of the greater Hudson Bay ( $29 \mathrm{psu})$ or SMOW (35 psu). The frost flowers analyzed had salinities of 5.1 to $23.4 \%$, far less than reported by other researchers for frost flowers growing on sea ice. Test hole frost flowers

Table 5. Ion Ratios and Sulfate and Bromide Ion Enrichment Relative to Chloride for Frost Flowers and Relevant Seawater ${ }^{\mathrm{a}}$

\begin{tabular}{|c|c|c|c|c|c|c|c|c|}
\hline Sample Identification & $\begin{array}{c}\text { Formation Air } \\
\text { Temperature }(\operatorname{deg} C)\end{array}$ & $\mathrm{Cl}^{-} / \mathrm{Na}^{+}$ & $\mathrm{Cl}^{-} / \mathrm{Br}^{-}$ & $\mathrm{SO}_{4}^{2-} / \mathrm{Na}^{+}$ & $\mathrm{SO}_{4}^{2-} / \mathrm{Cl}^{-}$ & $\mathrm{Na}^{+} / \mathrm{Br}^{-}$ & $\mathrm{SO}_{4}^{2-} / \mathrm{Cl}^{-} E_{f}$ & $\mathrm{Br}^{-} / \mathrm{Cl}^{-} E_{f}$ \\
\hline Nearshore water, 063W1 & & 1.77 & 357 & 0.24 & 0.14 & 201 & & \\
\hline 020308 test hole FF 4 & -24.6 & 2.06 & 306 & 0.32 & 0.16 & 149 & 1.16 & 1.17 \\
\hline 020308 test hole FF 5 & -24.6 & 2.06 & 314 & 0.32 & 0.16 & 152 & 1.15 & 1.13 \\
\hline 080308 test hole FF 4 & -25.5 & 2.06 & 272 & 0.32 & 0.15 & 132 & 1.14 & 1.31 \\
\hline 080308 test hole FF 5 & -25.5 & 2.09 & 356 & 0.29 & 0.14 & 171 & 1.01 & 1.00 \\
\hline Main bay water, $063 \mathrm{~W} 2$ & & 1.72 & 311 & 0.23 & 0.14 & 181 & & \\
\hline 060308 crack FF & -25.3 & 2.10 & 332 & 0.25 & 0.12 & 158 & 0.76 & 1.12 \\
\hline 090308 crack FF & -27.2 & 2.06 & 474 & 0.21 & 0.10 & 230 & 0.67 & 0.79 \\
\hline 110308 tidal FF, Bill of Portland & -21.7 & 2.08 & 391 & 0.27 & 0.13 & 188 & 0.94 & 0.79 \\
\hline 110308 tidal FF, Bill of Portland & -21.7 & 2.10 & 375 & 0.28 & 0.13 & 179 & 0.98 & 0.83 \\
\hline 120308 tidal FF, Maver Islands & -23.4 & 1.89 & 316 & 0.50 & 0.26 & 167 & 1.93 & 0.98 \\
\hline 120308 tidal FF, Maver Islands & -23.4 & 2.00 & 341 & 0.40 & 0.20 & 170 & 1.47 & 0.91 \\
\hline 120308 tidal FF, Maver Islands & -23.4 & 1.97 & 321 & 0.43 & 0.22 & 163 & 1.59 & 0.97 \\
\hline 130308 tidal FF, Maver Islands & -27.0 & 2.05 & 320 & 0.34 & 0.16 & 156 & 1.20 & 0.97 \\
\hline 130308 tidal FF, Maver Islands & -27.0 & 2.05 & 319 & 0.31 & 0.15 & 156 & 1.12 & 0.97 \\
\hline 130308 tidal FF, Maver Islands & -27.0 & 2.09 & 328 & 0.28 & 0.14 & 157 & 0.99 & 0.95 \\
\hline 130308 tidal FF, Maver Islands & -27.0 & 2.04 & 311 & 0.33 & 0.16 & 152 & 1.17 & 1.00 \\
\hline
\end{tabular}

${ }^{\mathrm{a}} \mathrm{See}$ text for explanation. 
were significantly salinity enhanced, compared to the local water, consistent with generally accepted theory that frost flowers derive their salinity from available brine, with brine channels an important source.

\subsection{Growth Time, Temperature, and Salinity of Frost Flowers}

[47] In general, a longer elapsed time since the start of growth leads to lower FF bulk salinity, as observed by other researchers [Perovich and Richter-Menge, 1994; AlvarezAviles et al., 2008]. For test hole frost flowers, this is due to further frost flower growth from the vapor. For tidal pool frost flowers, this may also be due to blowing snow caught on frost flowers or to desalination of the tidal pool through the melting of accumulated snow. Frost flowers from the crack and tidal pool locations, which had a renewable source of 21 psu water, became less saline with time. Frost flowers found in narrow tidal cracks, however, became more saline with time, despite further vapor deposition. These frost flowers were protected from blowing snow by the confines of the crack and were fed by undiluted water from the bay beneath. Hence, salinity can increase with time where a tidal source is available and not diluted.

[48] Frost flower bulk salinity decreased with decreasing air temperature for test hole frost flowers and for tidal frost flowers formed at temperatures below $-23^{\circ} \mathrm{C}$. Unless the seawater included melted sea ice as found by Alvarez-Aviles et al. [2008], for which we found no other evidence, this finding remains a mystery. Only in the crack frost flowers and in tidal frost flowers above $-23^{\circ} \mathrm{C}$ did bulk salinity increase despite decreasing temperature, as reported by other researchers [Perovich and Richter-Menge, 1994].

\subsection{Ion Enrichment, Growth Time, and Temperature}

[49] There is no quantitative correlation of bromide concentration with either temperature or growth time, although this could be related to lower overall bromide concentrations as a fraction of total ion concentration, making measurement error a greater proportion of the value.

[50] Comparisons between our data and that previously published may also be made. The $\mathrm{Cl} / \mathrm{Na}$ ratio for SMOW is 1.79 [Rankin et al., 2000]. Despite the lower salinity of the Hudson Bay, the $\mathrm{Cl} / \mathrm{Na}$ ratio found in water there is about the same: 1.77 nearshore and 1.72 outside the Bill of Portland Island. Frost flowers, however, had enhanced $\mathrm{Cl} / \mathrm{Na}$ ratios, ranging from 1.89 to 2.10 , which is an enrichment of $10 \%$ to $18 \%$. This result was unexpected. Even if precipitation of mirabilite removed all the available sulfate, which was not the case, only one eighth of the sodium would be lost. Our $\mathrm{Cl} / \mathrm{Na}$ enhancement was greater than that of $3 \%$ found in frost flowers collected by Rankin et al. [2000] in the Weddell Sea and than that of the 6\% in frost flowers collected by Simpson et al. [2005] near Barrow, and it remains another mystery.

[51] Bromide was enhanced (relative to chloride) in test hole frost flowers. In the other locations, we found $E_{f}(\mathrm{Br})$ close to unity, similar to Alvarez-Aviles et al. [2008] results in Barrow frost flowers. Simpson et al. [2005] found no bromide enrichment in Barrow test hole frost flowers, however Rankin found slight enhancement (1.14) at the Mertz Glacier (Antarctica), and Douglas found bromide enhancements of 1.30 to 1.93 in Barrow frost flowers
(T. A. Douglas, personal correspondence, 2009). These differences may be due to differences in formation temperature or other factors not consistently recorded in previous frost flower field studies.

\subsection{Growth Time, Specific Surface Area, and Temperature}

[52] Longer growth time at cold temperatures leads to higher SSA because of further dendritic growth. The correlation of SSA to growth time across all our samples was 0.71 , with correlations within a given location being even stronger. Frost flowers will continue to grow as long as supersaturation is adequate and they are undisturbed. Even with test hole frost flowers, where the surface of the ice appeared nearly dry, supersaturation was sufficient to lead to increased SSA after $26 \mathrm{~h}$. The types of macroscale (e.g., ribs) and microscale roughness (e.g., growth striations) shown in Figure 4 would also contribute to higher SSA, as would the collection of blowing snow. When temperatures rise and plates or needles are formed instead of dendritic structures, lower SSA may result. However, because frost flowers grow by step nucleation, and nearsurface temperature and supersaturation vary with time, tide, and wind, there is no single cutoff between these habits, and a mixture can be found at any given location.

[53] Frost flower SAI is negatively correlated (0.76) with temperature, and this is consistent with the assertion by Dominé et al. [2005] that brine on wet frost flowers smoothes out microstructures and leads to lower SAI values. However, more would need to be done to establish causality, as supersaturation is related to temperature and secondary crystal growth habit is based on both of these as well as on time. Further, any increase in SAI with colder temperatures would be offset by the opposite effect of temperature on the deposition and re-emission of sea salt aerosol, as warmer frost flower fields support greater relative humidity and air-ice exchange [Piot and von Glasow, 2008].

[54] In general, much more could be done on a systematic study of frost flower crystallography, as to date it has been largely based on a nonsystematic series of observations together with comparisons to the development of snow crystals. Frost flowers differ from snow in their constant orientation in space, their substrate, their brine and their chemistry, all of which may have implications for their growth and development.

[55] Dominé et al. [2005] calculated an SAI of $1.4 \mathrm{~m}^{2} \mathrm{~m}^{-2}$ for dry frost flowers by using SSA values measured on samples from Barrow and coverage observed at Spitsbergen. They went on to estimate TSA of less than $1 \mathrm{~m}^{2} \mathrm{~m}^{-2}$ for wet frost flowers. However, the frost flowers at Spitsbergen were described as wet and found in patches providing coverage of only $25 \%$. We believe this low coverage contributes to a somewhat low SAI value. We found coverage of $75 \%$ and $90 \%$ in the tidal pools and $100 \%$ in the test holes after $12 \mathrm{~h}$ and SAI of 1.8 to $2.1 \mathrm{~m}^{2} \mathrm{~m}^{-2}$.

\subsection{Influence of Frost Flowers on Atmospheric Chemistry}

[56] As discussed by Alvarez-Aviles et al. [2008] an immeasurably small amount of bromide depletion would be sufficient to cause the ozone depletion observed. Our results show bromide depletion relative to chloride in some 
samples, enrichment in others. The difference may be related to the loss of chloride due to hydrohalite $(\mathrm{NaCl}$. $2 \mathrm{H}_{2} \mathrm{O}$ ) precipitation at $-22^{\circ} \mathrm{C}$. Frost flowers do provide additional surface area on which the conversion of bromide in sea salt to $\mathrm{Br}_{2}$ can take place [Dominé et al., 2005], but they do not increase effective surface area by as much as has been speculated [Roscoe et al., 2001].

[57] This leaves open the question of whether they are the primary source of atmospheric reactive bromine [Kaleschke et al., 2004]. Dominé et al. [2005] speculate that surfaces where the sea salt coming from frost flowers is deposited may produce faster bromine activation, but we have observed that the threshold for blowing snow is lower than that for frost flower destruction, and our observations of frost flower rigidity suggest that, if frost flowers are contributing chemicals, it is more likely through scouring (of the frost flower surface by wind) than by fragmentation. Models developed by Piot and von Glasow [2008] produced results not supported by experimental data when the assumption was that bromine comes directly from the frost flower surfaces. Adding frost flower aerosols as a source improved results [Piot and von Glasow, 2008]. Further, the models suggest that to produce the best agreement with experimental data showing high bromine levels in the troposphere, the model of frost flower contributions must be augmented with the effect of bromine recycling on snow.

[58] We did not observe frost flowers in the act of breaking, but we saw large pieces of frost flowers lying just downwind of frost flower fields (the first time broken pieces have been observed) that were clearly too large to be lofted. We also observed that the wind speed threshold was much lower for snow mobilization than for frost flower breakage. Recently, blowing snow from a sea ice surface has been proposed as the source of reactive bromine [Simpson et al., 2005; Yang et al., 2008]. Legagneux et al. [2002] found SSA of snow between 100 and $1580 \mathrm{~cm}^{-2} \mathrm{~g}^{-1}$, depending on snow type and age, and SAI of several thousand $\mathrm{m}^{2} \mathrm{~m}^{-2}$. Our results suggest that blowing snow could be further salinated by contact with frost flowers, that perhaps the role of frost flowers by themselves has been overstated, and that it is the combination of frost flowers and blowing snow that forms the primary source of atmospheric reactive bromine.

[59] Acknowledgments. This work was funded under NERC grant $\mathrm{NE} / \mathrm{D} 006104 / 1$, "Impact of combined iodine and bromine release on the Arctic atmosphere (COBRA): An Arctic IPY consortium." The authors would like to thank Florent Dominé and Jean-Charles Gallet of the Laboratoire de Glaciologie et Géophysique de l'Environnement (LGGE) in France for hosting a visit and providing training on the BET method. The volumetric BET apparatus at the British Antarctic Survey was built on the basis of observations made of the apparatus at LGGE and with the additional advice of Michael Kerbrat of the Paul Scherrer Institute in Switzerland. The authors also wish to acknowledge their partners at the University of Leeds and the University of York for their logistical assistance before and during the field work.

\section{References}

Alvarez-Aviles, L., W. R. Simpson, T. A. Douglas, M. Sturm, D. Perovich, and F. Dominé (2008), Frost flower chemical composition during growth and its implications for aerosol production and bromine activation, J. Geophys. Res., 113, D21304, doi:10.1029/2008JD010277.

Barrie, L. A., J. W. Bottenheim, R. C. Schnell, P. J. Crutzen, and R. A. Rasmussen (1988), Ozone destruction and photochemical reactions at polar sunrise in the lower Arctic atmosphere, Nature, 334, 138-141, doi: $10.1038 / 334138 \mathrm{a} 0$.
Bottenheim, J. W., A. G. Gallant, and K. A. Brice (1986), Measurements of $\mathrm{NO}_{y}$ species and $\mathrm{O}_{3}$ at $82^{\circ} \mathrm{N}$ latitude, Geophys. Res. Lett., 13(2), $113-$ 116, doi:10.1029/GL013i002p00113.

Bottenheim, J. W., J. D. Fuentes, D. W. Tarasick, and K. G. Anlauf (2002), Ozone in the Arctic lower troposphere during winter and spring 2000 (ALERT2000), Atmos. Environ., 36(15-16), 2535-2544, doi:10.1016/ S1352-2310(02)00121-8.

Brunauer, S., P. H. Emmett, and E. Teller (1938), Adsorption of gases in multimolecular layers, J. Am. Chem. Soc., 60, 309-319, doi:10.1021/ ja01269a023.

Brunauer, S., L. S. Deming, W. E. Deming, and E. Teller (1940), On a theory of the Van Der Waals adsorption of gases, J. Am. Chem. Soc., 62, 1723-1732, doi:10.1021/ja01864a025.

Carpenter, L. J., J. R. Hopkins, C. E. Jones, A. C. Lewis, R. Parthipan, D. J. Wevill, L. Poissant, M. Pilote, and P. Constant (2005), Abiotic source of reactive organic halogens in the sub-arctic atmosphere?, Environ. Sci. Technol., 39(22), 8812-8816, doi:10.1021/es050918w.

Chaix, L., J. Ocampo, and F. Dominé (1996), Adsorption of $\mathrm{CH}_{4}$ on laboratory-made crushed ice and on natural snow at $77 \mathrm{~K}$ : Atmospheric implications, C. R. Acad. Sci, Ser. II, 322, 609-616.

Crocker, G. B., and J. E. Lewis (1985), Some physical properties of snow cover on evolving first year sea ice, paper presented at 42nd Eastern Snow Conference, Montreal, Canada, 6-7 June.

Déry, S. J., M. Stieglitz, E. C. McKenna, and E. F. Wood (2005), Characteristics and trends of river discharge into Hudson, James, and Ungava Bays, 1964-2000, J. Clim., 18(14), 2540-2557, doi:10.1175/ JCLI3440.1.

Dominé, F., L. Chaix, and L. Hanot (2000), Reanalysis and new measurements of $\mathrm{N}_{2}$ and $\mathrm{CH}_{4}$ adsorption on ice and snow, J. Colloid Interface Sci., 227, 104-110, doi:10.1006/jcis.2000.6883.

Dominé, F., A. Cabanes, and L. Legagneux (2002), Structure, microphysics and surface area of the Arctic snowpack near Alert during the ALERT 2000 campaign, Atmos. Environ., 36, 2753-2765, doi:10.1016/S13522310(02)00108-5.

Dominé, F., A. S. Taillandier, W. R. Simpson, and K. Severin (2005), Specific surface area, density and microstructure of frost flowers, Geophys. Res. Lett., 32, L13502, doi:10.1029/2005GL023245.

Drinkwater, M. R., and G. B. Crocker (1988), Modelling changes in the dialectric and scattering properties of young snow-covered sea ice at $\mathrm{GHz}$ frequencies, J. Glaciol., 34, 274-282.

Fan, S. M., and D. J. Jacob (1992), Surface ozone depletion in Arctic spring sustained by bromine reactions on aerosols, Nature, 359, 522-524, doi: $10.1038 / 359522 \mathrm{a} 0$.

Foster, K. L., R. A. Plastridge, J. W. Bottenheim, P. B. Shepson, B. J. Finlayson-Pitts, and C. W. Spicer (2001), The role of $\mathrm{Br}-2$ and $\mathrm{BrCl}$ in surface ozone destruction at polar sunrise, Science, 291(5503), 471-474, doi:10.1126/science.291.5503.471.

Gonda, T., and S. Nakahara (1997), Dendritic ice crystals with faceted tip growing from the vapor phase, J. Cryst. Growth, 173, 189-193, doi:10.1016/S0022-0248(96)00804-4

Hallett, J., and B. J. Mason (1958), The influence of temperature and supersaturation grown from the vapour, Proc. R. Soc., Ser. A, 247, $440-453$.

Hanot, L., and F. Dominé (1999), Evolution of the surface area of a snow layer, Environ. Sci. Technol., 33(23), 4250-4255, doi:10.1021/ es9811288.

Hoff, J. T., D. Gregor, D. Mackay, F. Wania, and C. Q. Jia (1998), Measurement of the specific surface area of snow with the nitrogen adsorption technique, Environ. Sci. Technol., 32(1), 58-62, doi:10.1021/es970225i.

Hopper, J. F., L. A. Barrie, A. Silis, W. Hart, A. J. Gallant, and H. Dryfhout (1998), Ozone and meteorology during the 1994 Polar Sunrise Experiment, J. Geophys. Res., 103, 1481-1492, doi:10.1029/97JD02888.

Ingram, R. G. (1981), Characteristics of the Great Whale River Plume, J. Geophys. Res., 86(C3), 2017-2023, doi:10.1029/JC086iC03p02017.

Ingram, R. G., and P. Larouche (1987), Variability of an under-ice river plume in Hudson Bay, J. Geophys. Res., 92(C9), 9541-9547, doi:10.1029/JC092iC09p09541.

Kaleschke, L., et al. (2004), Frost flowers on sea ice as a source of sea salt and their influence on tropospheric halogen chemistry, Geophys. Res. Lett., 31, L16114, doi:10.1029/2004GL020655.

Knight, C. A. (1972), Snow crystal growth habits, Trans. $A G U, 53,382$.

Legagneux, L., A. Cabanes, and F. Dominé (2002), Measurement of the specific surface area of 176 snow samples using methane adsorption at 77 K, J. Geophys. Res., 107(D17), 4335, doi:10.1029/2001JD001016.

Li, S. S., and R. G. Ingram (2007), Isopycnal deepening of an under-ice river plume in coastal waters: Field observations and modeling, J. Geophys. Res., 112, C07010, doi:10.1029/2006JC003883.

Makshtas, A. P. (1991), The Heat Budget of Arctic Ice in the Winter, translated from Russian by E. L. Andreas, 77 pp., Int. Glaciol. Soc., Cambridge, U. K. 
Martin, S., Y. Yu, and R. Drucker (1996), The temperature dependence of frost flower growth on laboratory sea ice and the effect of the flowers on the infrared observations of the surface, J. Geophys. Res., 101, 12,11112,125, doi:10.1029/96JC00208.

Mason, B. J. (1992), Snow crystals, natural and man made, Contemp. Phys., 33(4), 227-243, doi:10.1080/00107519208223972.

McConnell, J. C., G. S. Henderson, L. A. Barrie, J. Bottenheim, H. Niki, C. H. Langford, and E. M. J. Templeton (1992), Photochemical bromine production implicated in the Arctic boundary-layer ozone depletion, Nature, 355, 150-152, doi:10.1038/355150a0.

Nelson, J. (2001), Growth mechanisms to explain the primary and secondary habits of snow crystals, Philos. Mag. A, 81, 2337-2373.

Nelson, J. (2005), Branch growth and sidebranching in snow crystals, Cryst. Growth Design, 5(4), 1509-1525, doi:10.1021/cg049685v.

Perovich, D. K., and J. A. Richter-Menge (1994), Surface characteristics of lead ice, J. Geophys. Res., 99(C8), 16,341-16,350, doi:10.1029/ 94JC01194.

Piot, M., and R. von Glasow (2008), The potential importance of frost flowers, recycling on snow, and open leads for ozone depletion events, Atmos. Chem. Phys., 8, 2437-2467.

Rankin, A. M., V. Auld, and E. W. Wolff (2000), Frost flowers as a source of fractionated sea salt aerosol in the polar regions, Geophys. Res. Lett., 27(21), 3469-3472, doi:10.1029/2000GL011771.

Rankin, A. M., E. W. Wolff, and S. Martin (2002), Frost flowers: Implications for tropospheric chemistry and ice core interpretation, J. Geophys. Res., 107(D23), 4683, doi:10.1029/2002JD002492.

Richter, A., F. Wittrock, M. Eisinger, and J. P. Burrows (1998), GOME observations of tropospheric BrO in northern hemispheric spring and summer 1997, Geophys. Res. Lett., 25, 2683-2686, doi:10.1029/ 98GL52016.

Roscoe, H. K., K. Kreher, and U. Friess (2001), Ozone loss episodes in the free Antarctic troposphere, suggesting a possible climate feedback, Geophys. Res. Lett., 28, 2911-2914, doi:10.1029/2000GL012583.
Simpson, W. R., L. Alvarez-Aviles, T. A. Douglas, M. Sturm, and F. Dominé (2005), Halogen in the coastal snowpack near Barrow Alaska: Evidence for active bromine air-snow chemistry during springtime, Geophys. Res. Lett., 32, L04811, doi:10.1029/2004GL021748.

Spicer, C. W., et al. (2002), Molecular halogens before and during ozone depletion events in the Arctic at polar sunrise: Concentrations and sources, Atmos. Environ., 36(15-16), 2721-2731, doi:10.1016/S13522310(02)00125-5

Sturm, M., D. K. Perovich, and J. Holmgren (2002), Thermal conductivity and heat transfer through snow on the ice of the Beaufort Sea, J. Geophys. Res., 107(C10), 8043, doi:10.1029/2000JC000409.

Taillandier, A.-S., F. Domine, W. R. Simpson, M. Sturm, T. A. Douglas, and K. Severin (2006), Evolution of the Snow Area Index of the subarctic snowpack in Central Alaska over a whole season. Consequences for the air to snow transfer of pollutants, Environ. Sci. Technol., 40, 7521-7527, doi:10.1021/es060842j.

Thomas, D. N., and G. S. Dieckmann (2003), Sea Ice: An Introduction to its Physics, Chemistry, Biology and Geology, pp. 55-58, Blackwell Sci., Oxford, U. K.

Wagner, T., C. Leue, M. Wenig, K. Pfeilsticker, and U. Platt (2001), Spatial and temporal distribution of enhanced boundary layer $\mathrm{BrO}$ concentrations measured by the GOME instrument aboard ERS-2, J. Geophys. Res., 106, 24,225-24,235, doi:10.1029/2000JD000201.

Wolff, E. W., et al. (2003), An ice core indicator of Antarctic sea ice production?, Geophys. Res. Lett., 30(22), 2158, doi:10.1029/ 2003GL018454

Yang, X., J. A. Pyle, and R. A. Cox (2008), Sea salt aerosol production and bromine release: Role of snow on sea ice, Geophys. Res. Lett., 35, L16815, doi:10.1029/2008GL034536.

H. M. Atkinson, R. W. Obbard, H. K. Roscoe, and E. W. Wolff, British Antarctic Survey, Madingley Road, Cambridge CB3 0ET, UK. (hkro@bas. ac.uk) 